\title{
PENERAPAN PERLAKUAN AKUNTANSI ASET TETAP BERDASARKAN PSAK NO. 16 PADA HOTEL ARVIEL GORONTALO
}

\author{
Vionalisa Chandra ${ }^{1}$, Ventje Ilat ${ }^{2}$, Meily Y. B. Kalalo ${ }^{2}$ \\ ${ }^{1,2}$ Jurusan Akuntansi, Fakultas Ekonomi dan Bisnis, Universitas Sam Ratulangi, Jl. Kampus Bahu, \\ Manado, 95115, Indonesia \\ ${ }^{1}$ E-mail: vionalisac@gmail.com
}

\begin{abstract}
Assets remain the most important part in supporting the company's operational activities, especially for companies engaged in the hotel industry. Therefore, it is necessary to have an appropriate fixed asset accounting policy in accordance with PSAK No. 16. This study aims to determine how the recognition, measurement, and presentation of accounting for fixed assets based on PSAK No. 16 at the Arviel Gorontalo Hotel. This study uses qualitative approach that compares the actual situation with relevant theories related to the problem. The data obtained is the result of interviews and documentation. Analysis is done by comparing the financial statements of the Arviel Gorontalo Hotel with PSAK No. 16. The results show that the Arviel Hotel Gorontalo has not fully implemented the accounting for fixed assets in accordance with PSAK No. 16.
\end{abstract}

Keywords: application; accounting; fixed asset; PSAK No. 16

\section{PENDAHULUAN}

Aset tetap adalah suatu komponen yang dapat menunjang jalannya kegiatan operasional dalam menghasilkan laba atau keuntungan yang sesuai dengan harapan perusahaan sehingga guna memaksimalkan peran tersebut maka dibutuhkan kebijakan yang tepat dalam pengelolaan aset tetap (Pontoh et al., 2016). Beberapa komponen perlakuan akuntansi terhadap aset tetap adalah dimulai dari pengakuan aset tetap, perolehan aset tetap, pengeluaran setelah perolehan aset tetap, penyusutan aset tetap, penghentian dan pelepasan aset tetap, serta penyajian aset tetap dalam laporan keuangan.

Perlakuan akuntansi aset tetap sangat berpengaruh terhadap laporan keuangan khususnya yang berasal dari harga perolehan aset tetap, biaya operasional, dan jumlah laba (Sudiantara, 2018). Mengingat pentingnya laporan keuangan maka proses pencatatan dan penyajian aset tetap dari perusahaan sebaiknya sesuai dengan Pernyataan Standar Akuntansi Keuangan (PSAK) No. 16 sehingga dapat terhindar dari kesalahan yang dapat mempengaruhi pengambilan keputusan perusahaan.

Hotel Arviel Gorontalo merupakan salah satu perusahaan yang bergerak di bidang perhotelan. Perusahaan ini memiliki aset tetap yang terdiri dari tanah, bangunan, mesin dan perlengkapan, dan inventaris (AC, TV, kulkas, dan mebel) sebagai alat pendukung dalam melaksanakan kegiatan operasional perusahaan. Hotel Arviel Gorontalo memiliki jumlah aset kurang lebih 2 milyar dan masih memiliki banyak kendala mengenai pencatatan aset tetap yang belum sesuai dengan PSAK No. 16.

\section{TINJAUAN PUSTAKA}

Pengertian akuntansi keuangan. Menurut Weygandt et al. (2018:1-4), akuntansi keuangan adalah sebuah proses yang berakhir pada pembuatan laporan keuangan menyangkut perusahaan secara keseluruhan untuk digunakan baik pihak-pihak internal maupun pihak 
eksternal. Menurut Warren et al. (2018:492), akuntansi keuangan adalah pencatatan dan pelaporan data serta kegiatan ekonomi perusahaan.

Pengertian aset tetap. Menurut Munawir (2016:139), aset tetap merupakan aset berwujud yang memiliki umur yang lebih panjang. Aset tetap digunakan dalam operasional sehari-hari dan tidak untuk dijual kembali serta memiliki nilai yang relatif material. Menurut Hidayat (2011:4), aset adalah barang yang dalam pengertian hukum disebut sebagai suatu benda yang terdiri atas benda bergerak dan juga benda tidak bergerak, baik yang berwujud maupun tidak berwujud.

Klasifikasi aset tetap. Menurut Harahap (2015:126), aset tetap dapat dikelompokkan menurut sudut substansi yaitu aset berwujud (tangible assets) seperti lahan, mesin, gedung, dan peralatan. Aset yang tidak berwujud (intangible assets) seperti goodwill, paten, hak cipta, dan lain-lain. Pada konteks penyusutan aset tetap (depreciated plant assets) yaitu aset tetap yang disusutkan adalah bangunan, peralatan, mesin, inventaris, dan lain-lain sedangkan aset yang tidak dapat disusutkan (undepreciated plant assets) adalah tanah.

Pengakuan awal dan pengukuran biaya perolehan aset tetap. Berdasarkan PSAK No. 16, biaya perolehan aset tetap harus diakui jika: (a) besar kemungkinan manfaat ekonomi yang berkaitan dengan aset tetap dimasa depan mengalir ke entitas; dan (b) biaya perolehan aset tetap dapat diukur secara andal. Harga perolehan adalah harga beli ditambah seluruh biaya yang dikeluarkan untuk memperoleh dan menyiapkan hingga aset tetap tersebut siap digunakan (Wit dan Erhans, 2016:82). PSAK No. 16 menyebutkan bahwa suatu aset tetap yang memenuhi kualifikasi untuk diakui sebagai aset pada awalnya harus diukur sebesar biaya perolehan. Cara untuk mendapatkan atau memperoleh aset tetap adalah pembelian, pembelian dengan kontrak jangka panjang, aset tetap dengan konstruksi sendiri, dan aset tetap yang diperoleh dari sumbangan (Surya, 2015:152). Menurut Suhayati dan Anggadini (2017:68), pengeluaran-pengeluaran setelah perolehan aset tetap dapat diklasifikasi menjadi dua yaitu pengeluaran modal dan pengeluaran pendapatan.

Penyusutan aset tetap. Menurut PSAK No. 16, metode penyusutan antara lain metode garis lurus, metode saldo menurun, dan metode unit produksi. Menurut Weygandt et al. (2018:10-7), penyusutan merupakan suatu proses kapitalisasi aset tetap dengan cara mengalokasikan biaya perolehan aset berwujud ke beban dengan sistematis dan rasional selama periode manfaat dari penggunaan aset tetap. Fachruddin (2013) menyatakan bahwa aset yang mempunyai nilai cukup materil dan masa manfaat lebih dari satu periode, seharusnya diakui sebagai bagian dari aset tetap yang dimiliki perusahaan dan dicatatkan penyusutannya. Daniela (2014) menyarankan bahwa perusahaan diharapkan dapat meninjau setiap akhir tahun untuk setiap aset tetap yang mengalami penyusutan untuk melihat apakah ada perubahan umur ekonomis aset disesuaikan dengan kondisi fisik aset saat periode yang bersangkutan. Makaluas dan Pontoh (2018) menemukan bahwa perlu adanya pengendalian internal yang baik atas aset tetap agar kapitalisasi biaya perolehan dapat tersaji secara wajar dalam laporan keuangan. Soemarso (2009:25) menyatakan bahwa untuk menghitung penyusutan dapat dilakukan ada beberapa metode penyusutan yang dipakai di dalam praktek akuntansi yakni: (1) berdasarkan waktu yaitu metode garis lurus dan metode pembebanan menurun yang terdiri atas metode jumlah angka tahun, metode saldo menurun dan metode saldo menurun ganda; dan (2) berdasarkan penggunaan yaitu metode jumlah unit produksi dan metode jam jasa.

Penghentian, pelepasan, dan penyajian pada laporan keuangan atas aset tetap. Menurut PSAK No. 16, penghentian dan pelepasan aset tetap dilakukan pada saat jumlah tercatat aset tetap tersebut sudah tidak dapat diharapkan lagi untuk digunakan manfaat ekonominya di masa depan. Menurut PSAK No. 16, setiap jenis aset tetap harus diungkapkan dalam laporan keuangan, antara lain: (a) dasar pengukuran yang digunakan dalam menentukan jumlah tercatat bruto; (b) metode penyusutan yang digunakan; (c) umur manfaat 
atau tarif penyusutan yang digunakan; (d) jumlah tercatat bruto dan akumulasi penyusutan (digabungkan dengan akumulasi rugi penurunan nilai) pada awal dan akhir periode; dan (e) rekonsiliasi jumlah tercatat pada awal dan akhir periode.

\section{METODE PENELITIAN}

Penelitian ini menggunakan pendekatan kualitatif dengan metode analisis deskriptif dengan tujuan untuk mengungkapkan masalah dengan menggambarkan situasi atau kondisi yang benar-benar terjadi pada objek penelitian sehingga menghasilkan data yang bias dibandingkan dengan teori yang ada untuk menghasilkan kesimpulan dari permasalahan tersebut. Objek penelitian ini adalah Hotel Arviel Gorontalo yang terletak di Jl. Manggis, Kelurahan Molosipat W, Kecamatan Kota Barat, Kota Gorontalo.

Terdapat 2 (dua) jenis data yang digunakan dalam penelitian ini, yaitu: (1) data kualitatif berupa sejarah, letak objek, struktur organisasi, dan data lainnya yang diambil dari dokumen Hotel Arviel Gorontalo serta hasil wawancara yang diperoleh secara langsung dari objek penelitian; dan (2) data kuantitatif berupa jumlah aset tetap dan laporan keuangan tahun 2019 berupa neraca dan laporan laba rugi Hotel Arviel Gorontalo.

Sumber data penelitian adalah primer dimana data secara langsung didapatkan atau dikumpulkan dari objek penelitian dalam arti bahwa hasil wawancara secara langsung diperoleh dari pemilik, dan kepala bagian keuangan dan akuntansi dari Hotel Arviel Gorontalo berupa dokumentasi berupa daftar aset tetap beserta penyusutannya dan laporan keuangan. Teknik pengumpulan data dalam penelitian ini adalah: (1) wawancara langsung dengan pemilik, dan kepala bagian keuangan dan akuntansi Hotel Arviel Gorontalo; dan (2) dokumentasi atau pengumpulan dokumen pendukung penelitian terkait dengan aset tetap.

\section{HASIL PENELITIAN DAN PEMBAHASAN}

\subsection{Hasil penelitian}

Pengelompokan aset tetap. Aset tetap menjadi faktor yang paling utama dalam mendukung kelancaran kegiatan operasional perusahaan sehingga dapat mencapai tujuan yang telah ditetapkan. Aset tetap dikelompokkan karena mempunyai karakteristik, bentuk, serta jenis yang berbeda-beda. Hotel Arviel Gorontalo merupakan perusahaan yang bergerak di bidang penginapan yang memiliki aset tetap yang terdiri dari tanah, bangunan dengan masa manfaat 20 tahun, mesin dan inventaris dengan masa manfaat 8 tahun.

Perlakuan akuntansi aset tetap pada Hotel Arviel Gorontalo. Aset tetap pada Hotel Arviel Gorontalo diperoleh dengan cara dikonstruksi sendiri dan dengan pembelian tunai maupun kredit. Aset tetap kecuali tanah, dicatat berdasarkan harga perolehan berupa sejumlah uang yang digunakan untuk membayar aset tetap itu sendiri sesuai dengan yang tercantum dalam faktur beserta dengan pengeluaran-pengeluaran lain dan juga seluruh biaya yang dikeluarkan untuk memperoleh aset tetap, dikurangi akumulasi penyusutan. Tanah tidak disusutkan dan dinyatakan berdasarkan harga perolehan. Biaya perolehan awal aset tetap meliputi harga perolehan, berupa bea impor dan pajak pembelian yang tidak dapat dikreditkan beserta seluruh biaya yang dapat diatribusikan secara langsung sehingga dapat dibawa ke lokasi atau kondisi yang diinginkan. Pengeluaran modal atas aset tetap yang dibangun atau dikonstruksi sendiri seperti biaya material, tenaga kerja, dan lainnya belum dimasukkan dalam biaya perolehan aset tetap. Biaya yang dikeluarkan setelah perolehan aset tetap tidak dikelompokkan berdasarkan masa manfaat aset tetap tersebut. Biaya yang timbul setelah aset tetap digunakan, seperti biaya perbaikan dan pemeliharaan dicatat dengan jurnal perawatan dan dibebankan ke laporan laba rugi komprehensif pada periode terjadinya pengeluaran. Jika biaya tersebut menyebabkan meningkatnya masa manfaat suatu aset tetap di masa mendatang maka, biaya tersebut dapat dihitung sebagai penambahan atas biaya perolehan aset tetap tersebut. Penyusutannya dihitung berdasarkan taksiran umur manfaat 
ekonomi aset tetap menggunakan dua metode penyusutan yaitu metode penyusutan garis lurus untuk bangunan dan metode penyusutan saldo menurun untuk mesin, perlengkapan, dan inventaris. Pada akhir penggunaan aset tetap, Hotel Arviel Gorontalo melakukan pelepasan aset dengan menghentikan penggunaan aset tetap tersebut tanpa adanya pencatatan atau perhitungan atas aset tetap tersebut. Dalam laporan keuangan aset tetap dicantumkan berdasarkan biaya perolehan yang telah dikurangi akumulasi penyusutan.

\subsection{Pembahasan}

Klasifikasi dan pengakuan aset tetap berdasarkan PSAK No. 16. Klasifikasi aset tetap yang dilakukan oleh Hotel Arviel Gorontalo sudah sesuai dengan PSAK No. 16. Penelitian ini menemukan bahwa perlakuan akuntansi untuk pengakuan aset tetap yang diterapkan Hotel Arviel Gorontalo belum sesuai dengan PSAK No. 16 seperti yang tercantum dalam daftar aset tetap. Contoh, mesin genset 60 KVA memiliki ni lai biaya perolehan sebesar Rp. 85.000.000 tetapi belum termasuk biaya angkut Rp. 350.000, biaya pemasangan sebesar Rp. 250.000, dan biaya lain-lain sebesar Rp. 400.000.

Pengukuran aset tetap berdasarkan PSAK No. 16. Hotel Arviel Gorontalo mencatat transaksi saat dilakukan pembelian secara tunai sebuah Genset $60 \mathrm{KVA}$ dengan nilai sebesar Rp. 85.000.000 pada tahun 2014 dengan biaya angkut sebesar Rp. 350.000, biaya pemasangan sebesar Rp 250.000, dan biaya lain-lain sebesar Rp 400.000 dengan ayat jurnal berikut.

$$
\begin{array}{rr}
\text { Dr.Aset tetap (mesin) } & \text { Rp. } 85.000 .000 \\
\text { Cr. Kas } & \text { Rp. } 85.000 .000
\end{array}
$$

Ayat jurnal diatas belum tepat disebabkan pengeluaran atau biaya-biaya yang diakui sebagai harga perolehan merupakan harga beli aset tetap yang belum dibebankan biaya untuk memperoleh aset tetap tersebut seperti biaya angkut, biaya pemasangan, bea, dan pajak, sehingga ayat jurnal koreksi atas pemerolehan aset tetap disajikan berikut.

$$
\begin{array}{rr}
\text { Dr.Aset tetap (mesin) } & \text { Rp. } 86.000 .000 \\
\text { Cr. Kas } & \text { Rp. } 86.000 .000
\end{array}
$$

Pengeluaran setelah perolehan aset tetap. Pengeluaran pendapatan dapat berupa biaya yang digunakan untuk pemeliharaan aset seperti biaya perbaikan dan biaya pemeliharaan aset lainnya, sedangkan pengeluaran modal yaitu pengeluaran tidak rutin terjadi serta memiliki nilai yang cukup material dan masa manfaat lebih dari 1 (satu) tahun. Penelitian ini menemukan bahwa ayat jurnal Hotel Arviel Gorontalo atas perawatan rutin AC tiap bulan sebesar Rp. 75.000 dicatat sebagai berikut.

$$
\begin{array}{rr}
\text { Dr. Biaya perawatan (AC) } & \text { Rp. } 75.000 \\
\text { Cr. Kas } & \text { Rp. } 75.000
\end{array}
$$

Berdasarkan pencatatan diatas maka ayat jurnal koreksi atas perawatan rutin AC adalah.

$$
\begin{array}{rr}
\text { Dr. Biaya pemeliharaan (AC) } & \text { Rp. } 75.000 \\
\text { Cr. Kas } & \text { Rp. } 75.000
\end{array}
$$

Penyusutan aset tetap berdasarkan PSAK No. 16. Penelitian ini menemukan bahwa perlakuan akuntansi untuk penyusutan aset tetap yang diterapkan Hotel Arviel Gorontalo belum sepenuhnya sesuai dengan PSAK No. 16. Hal ini disebabkan Hotel Arviel Gorontalo melakukan penyusutannya sesuai dengan umur manfaat aset tetap dan tidak 
adanya tinjauan kembali untuk tiap tahunnya karena hanya berdasarkan pada umur manfaat aset tetap pada awal pengakuan.

Penghentian dan pelepasan aset tetap. Suatu aset tetap dihentikan penggunaannya dengan cara dijual, ditukar tambah dengan aset lainnya, atau dibuang. Penelitian ini menemukan bahwa Hotel Arviel Gorontalo belum melakukan pencatatan untuk aset tetap yang masa manfaatnya berakhir sehingga perlakuan akuntansi untuk penghentian dan pelepasan aset tetap yang diterapkan Hotel Arviel Gorontalo belum sepenuhnya sesuai dengan PSAK No. 16. Ayat jurnal koreksi atas meja senilai Rp. 500.000 yang akan dihentikan penggunaannya namun masih memiliki nilai buku senilai Rp. 100.000 adalah.

$$
\begin{array}{lr}
\text { Dr. Akumulasi penyusutan meja } & \text { Rp. } 400.000 \\
\text { Dr. Kerugian atas pelepasan aset tetap } & \text { Rp. } 100.000 \\
\text { Cr. Meja } & \text { Rp. } 500.000
\end{array}
$$

Penyajian aset tetap dalam neraca berdasarkan PSAK No. 16. Hotel Arviel Gorontalo sudah menyajikan komponen aset tetap yang tepat dalam neraca namun untuk penyajian akumulasi penyusutan tidak disajikan secara terpisah untuk masing-masing aset tetap. Akumulasi penyusutan disajikan dengan menggabungkan seluruh akumulasi penyusutan aset tetap seharusnya akumulasi penyusutan disajikan secara terpisah pada masing-masing aset tetap dalam laporan posisi keuangan.

\section{KESIMPULAN DAN SARAN}

\subsection{Kesimpulan}

Perlakuan akuntansi aset tetap yang diterapkan Hotel Arviel Gorontalo belum sepenuhnya sesuai dengan Pernyataan Standar Akuntansi Keuangan No. 16, terutama dalam hal berikut: (1) klasifikasi aset tetap; (2) pengakuan aset tetap khususnya pada biaya perolehan yang belum dapat diukur secara andal; (3) penghentian dan pelepasan aset tetap tidak tercantum dalam laporan keuangan sehingga tidak dapat diketahui kerugian yang muncul akibat pelepasan dan penghapusan aset tetap; (4) penyajian aset tetap pada laporan keuangan; dan (5) akumulasi penyusutan tidak disajikan secara terpisah untuk masing-masing aset tetap melainkan digabungkan.

\subsection{Saran}

Saran penelitian ini terkait perlakuan akuntansi aset tetap adalah: (1) biaya perolehannya dari aset tetap harus diukur secara andal berdasarkan harga beli beserta seluruh biaya yang dikeluarkan untuk memperoleh aset tetap tersebut; (2) penentuan biaya perolehan aset tetap yang diperoleh dari pembelian tunai maupun kredit perlu memperhatikan setiap pengeluaran-pengeluaran atau biaya yang terjadi selama perolehan aset tetap tersebut sampai siap untuk digunakan; (3) pengeluaran setelah perolehan aset tetap dapat menambah umur manfaat aset tetap tersebut sehingga diperlukan adanya pencatatan yang tepat sesuai dengan besarnya pengeluaran dan umur manfaatnya; (4) penyusutan aset tetap pada Hotel Arviel Gorontalo hendaknya dilakukan review tiap tahunnya; (5) menyajikan penghentian dan pelepasan aset tetap dalam laporan keuangan untuk mengetahui kerugian atas penghentian dan pelepasan atas aset tetap tersebut; dan (6) penyajian aset tetap dalam neraca pada Hotel Arviel Gorontalo akumulasi penyusutan untuk setiap aset tetap harus disajikan terpisah berdasarkan kelompoknya sehingga pemakai laporan keuangan bias memahami besarnya nilai penyusutan untuk setiap kelompok aset tetap. 


\section{DAFTAR PUSTAKA}

Daniela, A. (2014). Tinjauan atas pengakuan dan pengukuran aset tetap pada Win's Hotel. Tugas akhir. Sekolah Tinggi Ilmu Ekonomi Kesatuan Bogor. http://dx.doi.org/10.13140/RG.2.2.13936.92166

Fachruddin, M. (2013). Analisis akuntansi aset tetap pada Hotel Harsa Dumai. Skripsi. Universitas Negeri Sultan Syarif Kasim Riau. http://repository.uin-suska.ac.id/5407/

Harahap, S. S. (2015). Teori akuntansi, Edisi Revisi 2011. Jakarta: Rajawali Pers.

Hidayat, M. (2011). Manajemen aset (privat dan publik). Yogyakarta: Laks Bang.

Weygandt, J. J., Kimmel, P. D., \& Kieso, D. E. (2018). Accounting principles, $13^{\text {th }}$ Edition. New Jersey: John Wiley \& Sons, Inc.

Makaluas, J., \& Pontoh, W. (2018). Analysis of internal control of fixed assets in PT. Lumbung Berkat Indonesia. Jurnal Accountability, 7(01), 1-10. https://doi.org/10.32400/ja.19071.7.01.2018.1-10

Munawir, S. (2016). Analisa laporan keuangan, Edisi 4. Yogyakarta: Liberty.

Pernyataan Standar Akuntansi Keuangan No. 16 (Revisi 2015) Aset Tetap. Dewan Standar Akuntansi Keuangan. Jakarta: Ikatan Akuntan Indonesia.

Pontoh, E. L., J. Morasa., \& Budiarso, N. S. (2016). Evaluasi penerapan perlakuan akuntansi terhadap aktiva tetap berdasarkan PSAK No. 16 tahun 2011 pada PT. Nichindo Manado Suisan. Jurnal EMBA: Jurnal Riset Ekonomi, Manajemen, Bisnis dan Akuntansi, $\quad 4(3), \quad 68-77$. https://ejournal.unsrat.ac.id/index.php/emba/article/view/13391

Soemarso, S. R. (2009). Akuntansi suatu pengantar, Edisi 5, Buku 1. Jakarta: PT. Salemba Empat.

Sudiantara, G. (2018). Analisis perlakuan akuntansi aset tetap berwujud terhadap penyajian laporan keuangan pada Hotel Sayang Maha Mertha Jalan Lebak Bene (Melasti), Legian Kelod, Kuta. Universitas Pendidikan Ganesha Singaraja. Vokasi: Jurnal Riset Akuntansi, 7(1), 12-18. http://dx.doi.org/10.23887/vjra.v7i1.20740

Suhayati, E., \& Anggadini, S. D. (2017). Akuntansi keuangan. Yogyakarta: Graha Ilmu.

Surya, R. A. S. (2015). Akuntansi keuangan versi IFRS+. Yogyakarta: Graha Ilmu.

Warren, C. S., Reeve, J. M., \& Duchac, J. E. (2018). Financial accounting, 15th Edition. Boston: Cengage Learning.

Wit, \& Erhans. (2016). Akuntansi 1: Perusahaan jasa dan dagang. Jakarta: Ercontara Rajawali. 